TITLE:

\title{
Regeneration of dorsal column axons after spinal cord injury in young rats( Abstract_要旨)
}

$\operatorname{AUTHOR}(\mathrm{S})$ :

Kikukawa, Soki

\section{CITATION:}

Kikukawa, Soki. Regeneration of dorsal column axons after spinal cord injury in young rats. 京都大学, 1999, 博士(医学)

\section{ISSUE DATE:}

1999-03-23

URL:

http://hdl.handle.net/2433/181700

RIGHT: 


\section{【214】}

氏 名
学位 (専攻分野)
学位記番号
学位授与の日付
学位授与の要件
研究科 - 専攻
学位論文題目

篓乫素規

博 士 (医 学)

医 博 第 2084 号

平成 11 年 3 月 23 日

学位 規則第 4 条第 1 項該当

医学研究科脳統御医科学系専攻

Regeneration of dorsal column axons after spinal cord injury in young rats

（幼若ラットにおける脊䯣損傷後の索路の再生）

(主查)

論文調查委員教授金子武嗣教授柴崎浩教授川口三郎

\section{論文内 容 の 要旨}

脊髄損傷を修復して十分な機能回復を期待するならば，運動神経路だけでなく感覚神経路を再生させることが必要である。 錐体路は幼弱動物においては自然に再生し, 成熟動物においても人為的操作を加えることにより再生を誘導できるが, 後索 路は再生しないとされており，後索路と錐体路には再生能に本質的な違いがあると主張されている。その真偽を確かめるた め, 私達は幼若ラット春髄の後索路を両側性にT12-13レベルで鋭利に切断し, 切断線維の再生の有無を小麦胚芽凝集素（あ るいはコレラ毒素）結合ホースラディッシュペルオキシダーゼをトレーサーとする神経節越え標識法と蛍光色素結合デキス トランアミンをトレーサーとする逆行性標識法により検索した。一部の切片ではGFAP（glial fibrillary acidic protein）の 免疫染色を行って切断部のアストロサイトの反応を調べた。鋭利な切断の意図は軸索の周囲環境の破壞を最小限にとどめ,

軸索を誘導するような手掛かりができるだけ乱されないようにすることである。その結果, 神経節越え標識法で調べた $38 匹$ 中 7 匹において著明な再生が起こっており, 再生線維は正しい経路を通って正しい終止部位に終止していた。逆行性標識法

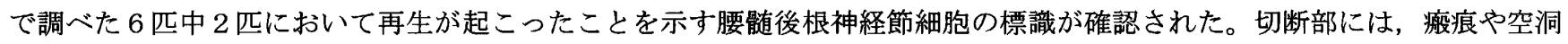
形成は認められなかったが，1）白質との境界部のニューロンが切断部の近傍で部分的に消失しているため, 細胞構築に不 連続性が認められ，2）想定される切断面に沿って所々に斑状に僅かなアストロサイトの増生があり，3）アストロサイト の突起が切断の方向に向いているといった所見によって, 切断の部位と切断された範囲を推測することは可能であり, その 範囲は両側の後索路を完全に含んでいた。しかし，それらの所見は余りにも痕跡的であるため切断部を同定する根拠として 第三者に説得力を持つとは思われないので, 本論文では完全切断の議論を避けて以下の 3 つの所見を再生の根拠とした。す なわち，1）切断部を越えて伸長する成長円錐が認められること，2）延娟薄束核における術後 9 日目の終末が対照動物に 見られるような微細な成熟型と異なり粗な未熟型であること，3）延髄薄束核に蛍光色素を注入すれば逆行性に切断部を越 えて腰髄後根神経節で神経細胞が標識されるが, その標識細胞が軸索切断後の反応である central chromatolysisを示すこ とである。本研究は，後索路が再生することを初めて証明し，後索路と錐体路の再生能に本質的な違いがないことを明らか にしたものである。

\section{論 文 審 查 の 結 果 の 要 旨}

機能的意義の高い春髄損傷の修復には，運動神経路だけでなく感覚神経路を再生されることが必要である。錐体路は幼若 動物においては自然に再生し，成熟動物においても人為的操作を加えることにより再生を誘導できるが，後索路は再生しな いとされており，後索路と錐体路には再生能に本質的な違いがあると主張されている。本研究はその真偽を確かめることを 目的として, 幼若ラット脊髄の後索路をT12-13レベルで両側性に切断し, 切断線維の再生の有無を神経節越え標識法と逆行 性標識法により検索した。切断は鋭利に行い，軸索の周囲環境の破壊を最小限にとどめ，軸索を誘導するような手掛かりが 
できるだけ失われないことを意図した。これらの動物において，成長円錐を伴った標識線維が切断部を越えて伸長し，正常 投射と同様に正常な経路を辿り同側の薄束核に密な終末を形成しているのが認められ, また, 腰遷後根神経節では多数の神 経細胞が逆行性に標識された。本研究結果は, 後索路が再生することを初めて証明し, 再生能に関して, 後索路と錐体路に 本質的な違いがないことを明らかにしたものである。

以上の研究は，春髄損傷の神経修復に展望を開くものであり，本論文は博士（医学）の学位論文として価値あるものと認 める。

なお，本学位授与申請者は，平成11年 1 月 19 日実施の論文内容とそれに関連した試問を受け合格と認められたものである。 